\title{
NEW MEMBER STATES OF THE EUROPEAN UNION AND THE CURRENT TRENDS IN THE WORLD ECONOMY
}

\author{
Bolotov, I.
}

This paper describes the specifics of the current development of the world economy and discusses implications for new member states of the European Union, the EU NMS, with a small case study on the Czech Republic. The paper is divided into four parts: the trends, the EU NMS and the effects of the trends in the EU NMS and in the Czech Republic. The paper is based on a general economic analysis of data provided by the World Bank (WB), the International Monetary Fund (IMF), Eurostat, the European Central Bank (ECB) and by the Czech Statistical Office (CZSO). Being familiar with recent macroeconomic trends is nowadays important for Central and Eastern European managers in order to efficiently adapt their strategies to the constantly changing business environment.

JEL classification: F01, F15, O52, P20

Keywords: world economy; crisis; European Union; new member states; Czech Republic

\section{Introduction}

The development of modern economies in the 2000s is different from the one observed in the 1970s, 1980s and also $1990 \mathrm{~s}$ in view of the strengthening role of crossborder trade (especially of intra-industry trade, intra-firm trade etc.), foreign investment, internationalization and innovation, as well as multinational and transnational companies (MNCs and TNCs). In addition, the recent global financial, economic and partly "debt" crisis of 2008 (also called "the Great Recession") was the first and largest global economic downturn since World War II, in many dimensions comparable to the economic crisis of 1930s (the Great Depression). The crisis significantly affected the economies of the U.S. and of the European Union (EU), in the latter - in both the old member states and the recent adherents, the so-called EU new member states (EU NMS) who joined the EU in 2004, 2007 and 2013: Bulgaria, Croatia, Cyprus, Czech Republic, Estonia, Hungary, Latvia, Lithuania, Malta, Poland, Romania, Slovakia and Slovenia. Growth has remained fragile since. This paper aims to describe, in a concise and informative manner, the specifics of the current development of the world economy and to discuss their effects in the mentioned EU NMS, with a short case study on the Czech Republic as one of the most developed economies.

\section{Methods}

The paper is divided into four parts, the trends, the EU NMS and the effects of these trends in the EU NMS with a special focus on the Czech Republic. The paper is based on general scientific methods of analysis, comparison, induction and synthesis in the form of general economic analysis performed on data from the World Bank (WB), the International Monetary Fund (IMF), the Organisation for Economic Co-operation and Development (OECD); from the European sources, Eurostat and the European Central Bank (ECB); and from the Czech Statistical Office (CZSO) and Czech National Bank (CNB). Not all data for the year 2013 was available in Q3 2014; therefore, Croatia is excluded from the EU NMS and EU list in tables. The most recent research on the topic was presented in (Baláž et al., 2010; Baldwin et al., 2009; Cihelková et al., 2009; Kalínská et al., 2010; Maddison, 
2004; Pettis, 2013; Štěrbová et al., 2013), Chapter 1, and in (Bolotov, Čajka, Gajdušková, 2013), Chapters 1 and 3.

\subsection{Trends in the Global Economic Development since 2000}

Recent literature on the world economy, international business and international trade, e.g. (Maddison, 2004; Pettis, 2013), in the Czech and Slovak languages, e.g. (Baláž et al., 2010; Cihelková et al., 2009; Kalínská et al., 2010; Štěrbová et al., 2013), states that the world economy has become a complex socio-economic system characterized by two mutually interconnected processes, globalization - an increased interconnection and interdependence between the majority of economies in the world, and regional integration - region/continent-based free trade agreements, customs unions, common markets, currency unions etc. with the EU as a successful example. The mutual interaction of both processes has created five trends in the world economy at the start of the $21^{\text {st }}$ century and especially in the current decade, 2010-2020, as described in (Baldwin et al., 2009; Štěrbová et al., 2013) and (Bolotov, Čajka, Gajdušková, 2013):

a) Continuous expansion of cross-border (international) trade in goods and services with an average growth rate of world exports and imports outperforming the growth of real world gross domestic product (GDP), 5.87-5.88\% against 3.44\% in 1991-2013 (IMF data, World Economic Outlook October 2014). This difference is mainly caused by the so-called compositional, synchronicity and statistical effects, as defined in (Baldwin et al., 2009; WTO, 2011, 2013), see Table 1.

Table 1: Three effects influencing the development of international trade

\begin{tabular}{|l|l|}
\hline Effect & \multicolumn{1}{c|}{ Significance } \\
\hline Compositional effect & $\begin{array}{l}\text { Higher share of 'postponable' } \\
\text { goods in the world trade than } \\
\text { in GDP, the demand } \\
\text { of which is more volatile than } \\
\text { the aggregate demand in } \\
\text { economies. }\end{array}$ \\
\hline Synchronicity effect & $\begin{array}{l}\text { Importance } \\
\text { of internationalized supply } \\
\text { chains, herd behavior. }\end{array}$ \\
\hline $\begin{array}{l}\text { Statistics / value-added } \\
\text { effect }\end{array}$ & $\begin{array}{l}\text { Rise in trade in intermediate } \\
\text { goods that leads to counting } \\
\text { the same value added more } \\
\text { than once in cross-border } \\
\text { trade flows. }\end{array}$ \\
\hline
\end{tabular}

Source: Bolotov, Čajka, and Gajdušková (2013), p. 13.
Durable goods dominate world trade with a greater share than the one of 50\% (WTO data, 2014), therefore it experiences higher demand fluctuations compared to service-oriented GDP, where services account for ca. 2/3-3/4 (WB data, 2014). This is amplified by implementation of new telecommunication technologies in supplier-buyernetworks and by on-going delocalization of industrial production and services towards Central and Eastern Europe, mainly the EU NMS, and towards Asia, notably China (and now also South-East Asia). The growth of trade is also spurred by liberalization through adoption of new regional trade agreements for example, the new free trade agreements between the EU and the Republic of Korea (July 2011) and Peru and Columbia (March and August 2013) - and through long-term negotiation rounds within the framework of the World Trade Organization (WTO), currently the Doha Development Agenda (since 2001).

b) Increase in foreign direct investment (FDI) flows, which quadrupled from 2004-2007 and reached their historical maximum of ca. 2 billion USD in 2007. The outflow of FDI for 2014 is projected to be slightly over 1.5 billion USD (reaching ca 1.75 billion USD in 2016, according to UNCTAD's World Investment Report 2014). FDI strengthens the position of MNCs and TNCs - today approximately $1 / 3$ of world trade is regarded as intrafirm conducted within MNCs and TNCs (UNCTAD data, 2013). According to an OECD study (Lanz and Miroudot, 2011), the extended MNCs' and TNCs' networks, based both on FDI and non-FDI types of relations, account for up to $2 / 3$ of exports and imports of goods and services in a number of developed economies; consult also Machková and Taušer (2013).

c) Internationalization of production of goods and services that decreases the role of countries in international trade and strengthens the position of MNCs and TNCs and their global value chains (GVCs) (Evan, 2011; UNCTAD 2013), e.g. Levi Strauss \& Co. produces cotton, fabric and clothes (jeans) in Mexico, Dominican Republic, Haiti, Egypt, which are later sold in the USA and Europe (Levi and Strauss, 2009). GVCs improve allocation of resources at the global level but their growth hampers the ability of international organizations, such as the WTO, UNCTAD and OECD, to accurately measure international trade as cross-border transactions include foreign value added. The share of foreign value added in cross-border exports, the strength of GVCs, varies from $3-7 \%$ in Saudi Arabia and Russia to almost 50 and $60 \%$ in Singapore and Luxembourg, according to OECD and WTO, TiVA data, 2014. 
Table 2: Basic facts and figures on the EU NMS in 2012

\begin{tabular}{|c|c|c|c|c|c|c|c|}
\hline \multirow{2}{*}{ Name / Code } & \multirow{2}{*}{$\begin{array}{c}\text { Area } \\
\text { th. sq. } \mathrm{km}\end{array}$} & \multicolumn{2}{|c|}{ Population } & \multicolumn{2}{|c|}{ GDP } & \multirow{2}{*}{$\begin{array}{l}\text { In the EU } \\
\text { since }\end{array}$} & \multirow{2}{*}{$\begin{array}{l}\text { In the euro } \\
\text { area since }\end{array}$} \\
\hline & & thousand & $\%$ of EU 27 & million EUR & $\%$ of EU 27 & & \\
\hline Cyprus & 9.3 & 862.0 & 0.17 & 16,259 & 0.12 & $5 / 1 / 04$ & $1 / 1 / 08$ \\
\hline Czech Republic & 77.3 & $10,505.4$ & 2.10 & 149,855 & 1.14 & $5 / 1 / 04$ & - \\
\hline Estonia & 43.4 & $1,333.8$ & 0.27 & 18,495 & 0.14 & $5 / 1 / 04$ & $1 / 1 / 11$ \\
\hline Hungary & 93.0 & $9,931.9$ & 1.98 & 98,048 & 0.75 & $5 / 1 / 04$ & - \\
\hline Latvia & 62.3 & $2,044.8$ & 0.41 & 23,375 & 0.18 & $5 / 1 / 04$ & $1 / 1 / 14$ \\
\hline Lithuania & 62.7 & $3,003.6$ & 0.60 & 34,705 & 0.26 & $5 / 1 / 04$ & ERM II \\
\hline Malta & 0.3 & 417.5 & 0.08 & 7,109 & 0.05 & $5 / 1 / 04$ & $1 / 1 / 08$ \\
\hline Poland & 312.7 & $38,538.4$ & 7.70 & 388,644 & 2.96 & $5 / 1 / 04$ & - \\
\hline Slovakia & 49.0 & $5,404.3$ & 1.08 & 72,791 & 0.55 & $5 / 1 / 04$ & $1 / 1 / 09$ \\
\hline Slovenia & 20.1 & $2,055.5$ & 0.41 & 34,955 & 0.27 & $5 / 1 / 04$ & $1 / 1 / 07$ \\
\hline Bulgaria & 111.0 & $7,327.2$ & 1.46 & 41,031 & 0.31 & $1 / 1 / 07$ & - \\
\hline Romania & 230.0 & $20,096.0$ & 4.02 & 141,563 & 1.08 & $1 / 1 / 07$ & - \\
\hline EU NMS & 1071.1 & 1279.5 & 20.28 & 1026.83 & 7.81 & $x$ & $x$ \\
\hline
\end{tabular}

Source: author, based on Eurostat data, 2014 and Europa.eu.

d) The growing share of developing and transitional econo-mies in the world economy, especially of the BRICS (Brazil, Russia, India, China and South Africa) - e.g. China became $2^{\text {nd }}$ in terms of both nominal GDP and GDP in purchasing power parity (PPP) in 2010 (8.4 trillion USD in 2013) and is expected to become the $1^{\text {st }}$ for PPP in 2014 (IMF data, 2014). Developing and transitional economies registered a total share of $42 \%$ in world trade in 2012-2013 and a greater than $50 \%$ share in global FDI inflows in 2013 with China and Russia being among top three investment destinations and top five investor nations (WTO and UNCTAD data, 2014). The share of the BRICS and of the EU NMS in the world GDP increased by $50-100 \%$ in $2000-2008$ (prior to the Global Recession) and in the case of the BRICS, continues to grow, as indicated by (Bolotov, Čajka, Gajdušková, 2013, p. 16) (WB data, 2014).

e) Higher instability of financial markets and the lasting effects of the global financial, economic and partly debt crisis of 2008, in which the world economy experienced a ca. $0.7-2.2 \%$ contraction in GDP in 2009 (IMF and WB data, 2014) and a slowdown since 2011 with growing signs of recovery only in the USA in 2014. In 2014, the instability was amplified by geopolitical risks resulting in worsening relationships and sanctions between the USA, EU, Canada, Australia, Japan, Switzerland, Norway and Russia due to the Ukrainian crisis, as well as to other crises and problems, such as the Middle East (Iraq and Syria), Ebola outbreak, etc.

\subsection{The New Member States of the European Union, the EU NMS}

The EU NMS are a group of countries that acceded to the EU during the 2004, 2007 and 2013 enlargements (countries, which will accede in the future will be also added to the EU NMS list): Bulgaria, Croatia, Cyprus, Czech Republic, Estonia, Hungary, Latvia, Lithuania, Malta, Poland, Romania, Slovakia and Slovenia. Ten of these countries are former socialist economies, part of which emerged in the beginning of the 1990s with the dissolution of the USSR (1991), Yugoslavia (1991-1992) and Czechoslovakia (1993). Hence they have undergone a profound economic transition since the 1990s, which has already finished in some countries, in Estonia, the Czech Republic, Slovakia and Slovenia (possibly also in Hungary and in Poland) and continues in the rest, consult Table 2. Cyprus and Malta share a different historical background and are considered to be developed economies by the IMF / WB.

The EU NMS vary greatly in size and in economic development, ranging from 0.3 to 312.7 thousand sq. $\mathrm{km}$, from 0.4 to 38.5 million inhabitants and, in terms of GDP per capita in PPP, from 47 to $91 \%$ of the EU 27 level, consult Table 3. The same is valid for price levels: the lowest value corresponds to $49 \%$ and the highest to $88 \%$ of the EU 27 average. 
Table 3: Comparison of economic level of the EU NMS and the EU 27 in 2012

\begin{tabular}{|l|c|r|r|}
\hline \multirow{2}{*}{} & \multicolumn{2}{|c|}{$\begin{array}{c}\text { GDP per capita, } \\
\text { PPP }\end{array}$} & $\begin{array}{c}\text { Price } \\
\text { level }\end{array}$ \\
\cline { 2 - 4 } & EUR & $\%$ & $\%$ \\
\hline European Union (EU 27) & 25600 & 100 & 100 \\
\hline EU NMS (average) & 19098 & 75 & 71 \\
\hline Cyprus & 23296 & 91 & 88 \\
\hline Czech Republic & 20224 & 79 & 75 \\
\hline Estonia & 17664 & 69 & 80 \\
\hline Hungary & 16896 & 66 & 62 \\
\hline Latvia & 15872 & 62 & 75 \\
\hline Lithuania & 17920 & 70 & 66 \\
\hline Malta & 22016 & 86 & 78 \\
\hline Poland & 16896 & 66 & 58 \\
\hline Slovakia & 19200 & 75 & 72 \\
\hline Slovenia & 20992 & 82 & 85 \\
\hline Bulgaria & 12032 & 47 & 49 \\
\hline Romania & 12544 & 49 & 57 \\
\hline
\end{tabular}

Source: author, based on Eurostat data, 2014.

The EU NMS are an economically developing segment of the EU: with approximately $24.8 \%$ of its territory and $20.3 \%$ of its population, in 2012 the EU NMS accounted for only $7.8 \%$ of the EU 27 's GDP, $18.2 \%$ of its agricultural production, $10.7 \%$ of its industrial production, $10.6 \%$ of its total exports and $10.8 \%$ of its total import; consult Table 4 for indicators.
Table 4: Comparison of economic indicators of the EU NMS and the EU 27, 2004-2012

\begin{tabular}{|l|c|c|}
\hline & EU 27 & EU NMS \\
\hline Real GDP growth, \% & 1.2 & 2.9 \\
\hline Inflation rate, consumer prices, \% & 2.4 & 4.1 \\
\hline Unemployment rate, \% of labor force & 8.9 & 9.1 \\
\hline Public debt, \% of GDP & 70.0 & 38.2 \\
\hline Current account deficit, \% of GDP & 0.3 & -5.9 \\
\hline
\end{tabular}

Source: author, based on Eurostat data, 2014.

\subsection{The EU NMS and the Recent Global Trends in the World Economy}

The lower price level, lower labor costs and important investment incentives enable production to be delocalized from developed countries in EU 27 and in the world to the EU NMS. By means of examples, in the 2000s, automotive companies like Volkswagen, PSA, and Toyota moved their production to the Czech Republic, Hungary and Slovakia, Danish toy producer LEGO to Poland etc. This renders the EU NMS an important part of global value chains (GVC). From Table 5 it can be observed that foreign value added in a EU NMS country's exports since 1995 - quadrupled for the Czech Republic, ten-folded for Estonia and increased 25 times in the case of Slovakia and was introduced in Lithuania where it was almost non-existent. The EU, however, remains their main trading partner and the largest investor in the new member states, as indicated by Eurostat data.

Table 5: Foreign value added in the gross exports of the selected EU NMS, million USD

\begin{tabular}{|c|c|c|c|c|c|c|c|c|}
\hline & \multicolumn{4}{|c|}{ Total } & \multicolumn{4}{|c|}{ Transport equipment } \\
\hline & 1995 & 2000 & 2005 & 2008 & 1995 & 2000 & 2005 & 2008 \\
\hline EU 27 & 91150.8 & 134550.1 & 237536.2 & 402394.5 & 10078.2 & 15704.8 & 25096.9 & 44557.3 \\
\hline Slovenia & 3039.4 & 3834.2 & 8718.2 & 13628.4 & 481.5 & 637.5 & 1404.8 & 1803 \\
\hline Slovakia & 3981.2 & 6838.2 & 17257.7 & 37530.7 & 429.8 & 1616 & 4047.9 & 10735.8 \\
\hline Poland & 4750.4 & 10255.7 & 32996 & 61318.6 & 387.6 & 1740.2 & 7401.8 & 14109 \\
\hline Lithuania & 990 & 1580.5 & 5478.8 & 11013.2 & 0 & 25.7 & 88.6 & 214 \\
\hline Latvia & 431 & 762.8 & 2102.7 & 3943.6 & 9.1 & 14.7 & 42 & 84.6 \\
\hline Hungary & 4939.1 & 14248.6 & 31857 & 50849.3 & 343.6 & 2650.8 & 6864.2 & 11321.9 \\
\hline Estonia & 1065.1 & 2298.6 & 4931.1 & 6141.6 & 16.7 & 40.2 & 162.6 & 173.8 \\
\hline Czech Republic & 8490.2 & 13387.3 & 32536.4 & 55300.6 & 890.6 & 2842.6 & 7446.1 & 9679 \\
\hline
\end{tabular}

Source: author, based on OECD-WTO, TiVA, 2014. 
The openness to trade in goods and services and to FDI inflows of the ten largest EU NMS also substantially increased since the 1990s. The most open economies in 2013 were Estonia, Hungary and Slovakia. For some countries, the share of total trade (sum of export and import) in GDP exceeded $180 \%$, which means that $90 \%$ of what was produced within their territory entered cross-border trade. The share of FDI in GDP was smaller, nevertheless significant (5-10\% of GDP) and played the role of stabilizer, as indicated in (Bolotov 2012, 2013). For the specifics of the EU NMS balance of payments, consult also Kondrashov and Síma (2014).

\subsection{Case Study of the Czech Republic}

In 2013, the Czech Republic (CR) was the $15^{\text {th }}$ largest and the $11^{\text {th }}$ most populous member state in the EU 27 and EU 28, as well as its sixteenth largest and the $17^{\text {th }}$ most developed economy in terms of GDP and GDP per capita in the purchasing power standard (PPS), according to Eurostat. The economic development of the CR since EU accession has been above par for all basic macroeconomic indicators, as displayed in Table 6 . In general, the structure of the Czech economy has not been subject to major changes since 1993 except for ownership, followed by privatization and important FDI inflows. The CZSO (Dubská, 2012) states that foreign capital controls about $97 \%$ of assets in the Czech banking sector, and its share in manufacturing turnover surpassed 50\% in 2002 and accounts for more than $80 \%$ in the automotive industry. Export-orientation and high productivity, a substantially greater share in production (value added, VA) compared with the one in employment, places foreign-controlled companies in a better position when compared to less efficient domestic ones.

Table 6: Economic indicators of the EU NMS and of the Czech Republic, 2004-2012

\begin{tabular}{|l|c|c|}
\hline & $\begin{array}{c}\text { EU } \\
\text { NMS }\end{array}$ & $\begin{array}{c}\text { Czech } \\
\text { Republic }\end{array}$ \\
\hline Real GDP growth, \% & 2.9 & 2.9 \\
\hline Inflation rate, consumer prices, \% & 4.1 & 2.7 \\
\hline Unemployment rate, \% of labor force & 9.1 & 6.7 \\
\hline Public debt, \% of GDP & 38.2 & 33.5 \\
\hline Current account deficit, \% of GDP & -5.9 & -2.9 \\
\hline
\end{tabular}

Source: author, based on Eurostat data, 2014.

Figure 1: Statistical discrepancies in the Czech external trade, CZK bn., 1996-2013

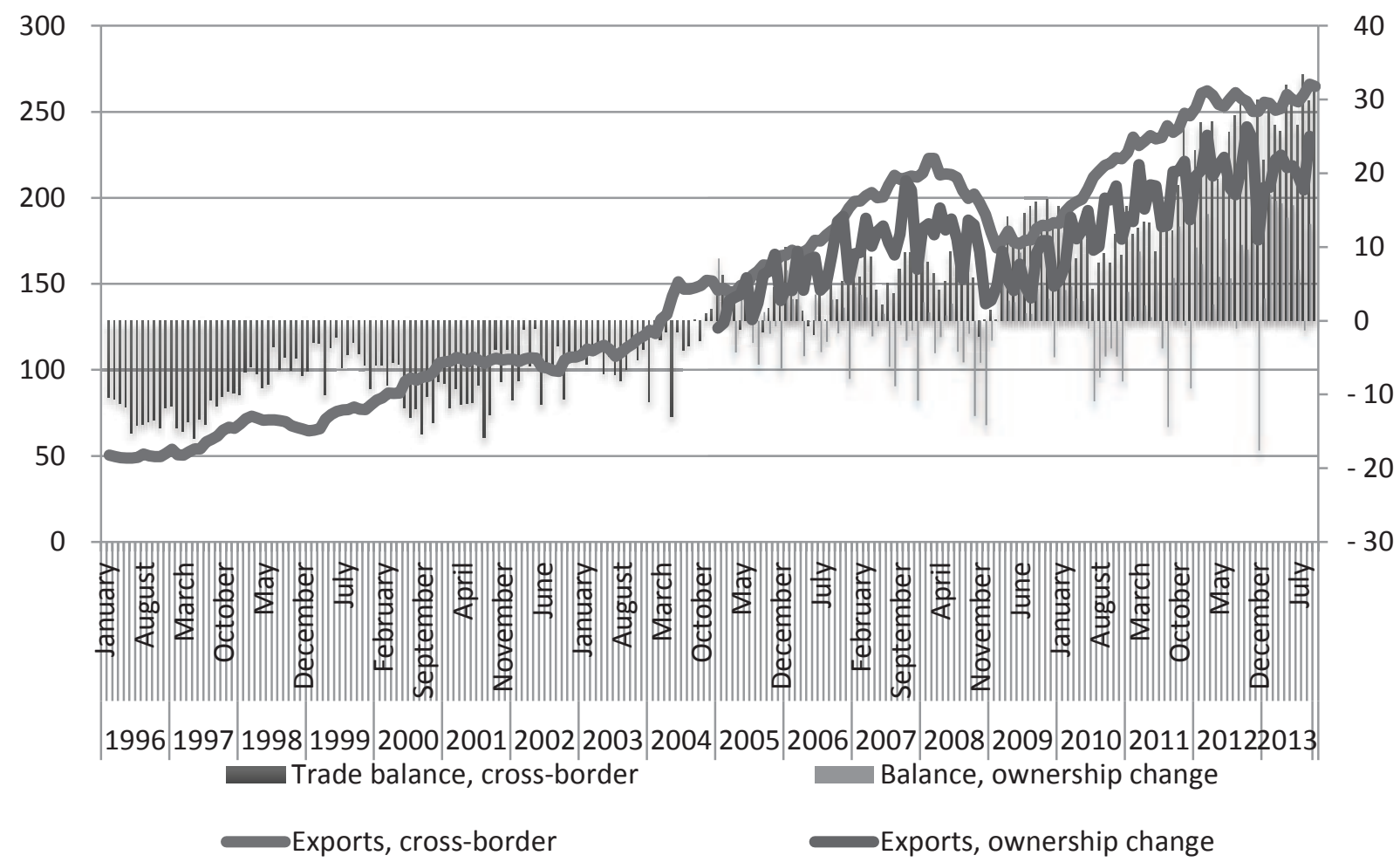

Source: author, based on CZSO data, 2014. 
The dual economy is especially perceived in retail trade of which, in $2010,76.5 \%$ of turnover was created by the TOP 10 foreign-controlled firms (Machek 2012), while the share of all foreign-controlled companies in the industry's employment was seven times lower, approximately $10 \%$ in the same year. As other examples, the three largest Czech mobile operators were acquired by Telefonica / $\mathrm{O}_{2}$, Vodafone and T-Mobile, and in 2013, 44\% of Czech Airlines' shares were sold to Korean Air by the Czech government. Despite important market saturation, Czech industries remain lucrative for foreign companies due to investment incentives and lower labor costs, as indicated in (Bolotov, Čajka, Gajdušková, 2013, p. 71).

New trends in the world economy have had a specific impact on Czech external trade. The value added tax (VAT) registration in the $\mathrm{CR}$ enables non-resident EU-based companies to be viewed as Czech exporters and importers. Today, Hungary and the CR are the only EU NMS countries, which experience relatively large differences in cross-border / gross and national (ownership change, residents, non-residents) methods of calculation of external trade. In 2012 the corresponding difference constituted approximately $6 \%$ of Czech GDP, consult Figure 1. The main reasons for the discrepancies in the Czech foreign trade are 1) hire of storehouses by non-residents for re-export and transit trade business and 2) intra-firm trade inside multinational and transnational corporations (MNCs and TNCs), which leads to deviations between producer and exporter prices - e.g. automotive products are usually exported via TNC's special trade companies after being purchased from the producer ones in the $\mathrm{CR}$.

\section{Conclusion and Managerial Implications}

The paper showed that the EU new member states possess certain specifics over the European Union as a whole: rapid development compared to the EU 27, lower general government and private debt, current account deficits and important inflows of foreign direct investment. Their engagement in the new trends of the world economy is, despite these differences, relatively high in terms of openness and foreign value added. They have become an important destination for outsourcing and hence a part of global value chains. It can especially be seen in the case of the Czech Republic, which has a significant share of foreign value added in its exports and is subject to differences between cross-border and national (residents-non-residents) trade.

The development of the world economy is rapid and its new trends represent opportunities in cost reduction or possible threats to companies. Being familiar with recent macro and business changes is important for Central and Eastern European managers in order to efficiently adapt their strategies to the constantly changing business environment and to overcome the current post-crisis slowdown.

\section{References}

Baláž, P. et al. (2010). Medzinárodné podnikanie na vlne globalizujúcej sa svetovej ekonomiky [International business on the wave of the world economy's ongoing globalization]. Bratislava: Sprint dva.

Baldwin, R. et al. (ed.) (2009). The Great Trade Collapse: Causes, Consequences and Prospects. (accessed September 27, 2014), [available at http://www.voxeu.org/epubs/cepr-reports/ great-trade-collapse-causes-consequences-and-prospects].

Bolotov, I. (2012). Foreign Capital Inflow Structure: Theoretical Explanation and Connection with Macroeconomic Indicators in the years 2008 and 2009. Aktualnye problemy ekonomiki i prava, 23 (3): 67-72.

Bolotov, I. (2013). The Internal Balance of the EU New Member States During the Financial and Economic Crisis: A case Study of the Importance of Foreign Capital Inflow Structure. Aktualnye problemy ekonomiki i prava, 25 (1): 48-54.

Bolotov, I., Čajka, R., Gajdušková, K. (2013). Economic Development of the EU New Member States. The impact of the crisis and the role of the single European Currency. Prague: Nakladatelství Oeconomica.

Cihelková, E. et al. (ed.) (2009). Světová ekonomika. Obecné trendy rozvoje. [World economy. General development trends]. Prague: C.H.Beck Publishing House.

Dubská, D. (2012). Zahraniční firmy v ČR [Foreign companies in the Czech Republic]. (accessed September 27, 2014), [available at http://www.czso.cz/csu/tz.nsf/i/ prezentace_z_tk_vliv_zahranicnich_firem_v_cr/\$File/ csu_tk_zahranicni_firmy_prezentace.pdf].

Evan, T. (2011). Př́mé zahraniční investice jako nástroj nadnárodních společností [Foreign direct investment as a tool for multinational companies]. in Globalizace a regionalizace mezi vládní politikou a tržním prostředím, ed. Evan, T. Prague: VŠRR, 57-62.

Kalínská, E. et al. (2010). Mezinárodní obchod v 21. století [International trade in the $21^{\text {st }}$ century]. Prague: Grada Publishing.

Kondrashov, A., Šíma, O. (2014) The effects of tourism on the balance of payments of the EU countries. Scientia et Societas, 10 (1): 26-38.

Lanz, R., Miroudot, S. (2011). Intra-Firm Trade: Patterns, Determinants and Policy Implications. OECD Trade Policy Papers, 114. 
Levi Strauss \& Co. (2009): A product Lifecycle Approach to Sustainability. (accessed September 27, 2014), [available at http://sco.s3.amazonaws.com/wp-content/uploads/ 2014/01/ A-Product-Lifecyle-Approach-to-Sustainability.pdf].

Machek, M. (2012). Retail Market Structure Development in Central Europe. Central European Business Review, 1 (3): $22-27$.

Machková, H., Taušer, J. (2013). Outsourcing jako kapitálově nenáročná forma mezinárodního podnikání [Outsourcing as a non-capital-intensive form of international business]. Scientia et Societas, 9 (1): 79-86.

Maddison, A. (2004). The World Economy. Paris: OECD.

Pettis, M. (2013). The Great Rebalancing: Trade, Conflict, and the Perilous Road Ahead for the World Economy. Princeton: Princeton University Press.

Štěrbová, L. et al. (2013). Mezinárodní obchod ve světové krizi 21. stoleti [International trade amidst the global crisis of the $21^{\text {st }}$ century]. Prague: Grada Publishing.

UNCTAD (2013). World Investment Report 2013: Global Value Chains - Investment and Trade for Development. Geneva and New York: UNCTAD.
WTO (2011). Trade growth to ease in 2011 but despite 2010 record surge, crisis hangover persists (accessed September 27, 2014), [available at http://www.wto.org/english/ news_e/pres11_e/pr628_e.htm].

WTO (2013). Trade to remain subdued in 2013 after sluggish growth in 2012 as European economies continue to struggle. (accessed September 27, 2014), [available at http://wto.org/english/news_e/pres13_e/pr688_e.htm].

\section{Author}

Ing. Ilya Bolotov, Ph.D., MBA Faculty of International Relations, Department of International Trade University of Economics, Prague nám. W. Churchilla 4, 130 67, Prague, Czech Republic ilya.bolotov@vse.cz

This paper was elaborated under the institutional support of the Faculty of International Relations, University of Economics, Prague, project No. IP200040 